\title{
«ПЛАСТИЧНА ДРАМАТУРГІЯ» ДАНИЛА ЛІДЕРА
}

У статті розглянуто методологічні засади творчої діяльності Данила Лідера в контексті мистецтвва художників дієвої сиенографії «великого стилю». Основна увага акиентована на співпрачі режисера і сценографа, знаходження ними спільних критерїв при формуванні образу-задуму просторово-пластичних систем сценічного твору.

Ключові слова: Данило Лідер, украӥнський театр, сценографія, образна система вистави.

В статье рассмотрены методологические принципь творческой деятельности Даниила Лидера в контексте искусства художников действенной сценографии «большого стиля». Основное внимание акиентировано на со-творчестве режиссера и сиенографа, нахождении ими общих критериев в формировании образа-замысла пространственно-пластической системы спектакля.

Ключевые слова: Даниил Лидер, украинский театр, сценография, образная система спектакля.

The article deals with methodological principles of Danil Lider's creative activity in the context of the art of artists of the "big style» effective scenography. The main emphasis is placed on collaboration of the director and the scenographer and their finding of common criteria to form the image-design of the spaceplastic systems of the stage work.

Key words: D. Lider, stage design, Ukrainian theater, figurative performance system.

На конференції театральних художників «Традиції і новаторство в мистецтві», організованій Українським театральним товариством 1966 року, Данило Лідер акцентував увагу на тому, що сьогодні для сценографів «Важливе не місце дії, а щзо відбувається у кожному акті драматургії. Навколо “що”, а не “де”, слід зосереджувати свою увагу» [1]. Ця теза, по суті, підводила підсумок початкового етапу становлення принципів «дієвої сценографії» - періоду, коли когорта провідних сценографів країни (таких, як Д. Лідер, С. Бархін, Д. Боровський, І. Блумберг, Г. Гунія, Е. Кочергін, М. Кітаєв, В. Левенталь, Т. Сельвінська, Е. Стенберг, I. Сумбаташвілі та ін.) у своїх роботах дедалі активніше почала долучатися до спільного 3 режисерами процесу побудови сценічної дії.

Впродовж наступних десятиліть художники, наполегливо накопичуючи «банк» просторово-пластичних ідей, утверджували сценографію як самостійний вид мистецтва й активно сприяли становленню нового характеру співтворчості з режисурою у створенні образної системи вистави. Цей процес визначив одну з головних тенденцій розвитку естетики театру - прагнення митців максимально розширити межі доступного сцені, представити у спектаклі незакріплені в словах драматурга лики часу та рівні пізнання світу.
У театрознавчих дослідженнях широко висвітлено вплив «дієвої сценографії» на розвиток образної мови театру. Значно меншу увагу приділено аналізу творчих засад співпраці режисерів і сценографів, знаходження ними спільних критеріїв при формуванні образу-задуму вистави. Представлена стаття розглядає деякі аспекти цього процесу в мистецтві Данила Лідера.

У 1981 році у публікації «Роздуми художника» Д. Лідер писав: «У принципі, в мене схема підходу до будь-якого матеріалу в період, так би мовити, передуючий втіленню замислу, така:

- вивчення всього комплексу питань, пов'язаних із даною п'єсою, з особливостями поетики автора, кола постійних проблем, сфери ідей тощо;

- потім я намагаюсь якомога точніше виділити головні та другорядні проблеми в даному творі;

- потім намагаюся роздивитися та уяснити для себе проблеми нашого сьогодення, аналогічні й співзвучні тим, що поставлені у п'єсі;

- формулюю свої особистісні позиції стосовно проблем, що містяться в тексті, й стосовно проблем дійсності, відбитих у драматургії;

$-\mathrm{i}$, нарешті, визначаю для себе характер образності» [2, 203-206].

Стосовно останнього, то Д. Лідер вважає за необхідне дати відповідь на такі питання: 
«...як узагальнити матеріал п’єси, за якими законами? Які її події будувати по лінії образності? Як розглядати матеріал п’єси — через метафору або алегорію? Через які матеріальні предмети виразити метафору? Адже речі, предмети, реальний світ вступають в образному театрі в особливі, суто людські відносини, коли у повну силу діють образні асоціації» $[3,7]$.

Визначення «характеру образності», цілком природно, міститься на території творчості сценографа. Однак, ретельно прописуючи етапи роботи 3 драматургічним матеріалом, Д. Лідер жодною фразою не обмовився про режисерську інтерпретацію п'єси. Важко уявити, щоб у процесі створення зорового образу вистави Д. Боровський не враховував режисерську концепцію Ю. Любимова, Е. Кочергін - Г. Товстоногова, М. Кітаєв А. Шапіро, В. Левенталь - А. Ефроса, О. Шейціс - М. Захарова, М. Шевелідзе - Р. Стуруа, В. Славкін - А. Васильєва та ін.

Така особливість творчості Д. Лідера не лишилася поза увагою театрознавців. Досліджуючи проблеми становлення і розвитку «дієвої сценографії», В. Берьозкін зазначав, що «пластична режисура» була тим підгрунтям, на якому базувалася співтворчість одного з найбільш яскравих режисерсько-сценографічних тандемів - Ю. Любимова i Д. Боровського. Для характеристики мистецтва Д. Лідера слід ввести термін «пластична драматургія». Розуміючи всю умовність такого визначення, В. Берьозкін у такий спосіб акцентував увагу на цільовій установці художника - «побудові такого пластичного образу, що розвивається у просторі та часі, чий багатозначний ідейно-художній смисл розкривається у зв’язку з подіями, котрі відбуваються на сцені. Ці події обумовлені п’єсою, для Лідера вони є об'єктивною даністю, що існує незалежно від того, як буде побудована режисерська партитура спектаклю» [4, 115].

У контексті цих спостережень показовим $є$ такий фрагмент бесіди Д. Лідера $з$ театрознавцем О. Клековкіним: «Я сказав тому режисерові: знаєш, якщо погоджуся на роботу 3 тобою, то сам i ставити буду - своє. Тобі це треба?<..>.

Коли мені запропонували ставити у МХАТі “Вишневий сад”, я сказав, що можу лише повторити вже зроблене. Бо не було й нема причин робити щось інакше. Мене запитують - хіба так буває?

Так буває. Бо дуже великий був розбіг. Я жив у ньому рік-два, програв спектакль не інакше, а багатіше.
Мені сказали: Данило Данилович, варіанти потрібні. А я не знав, навіщо. Я не переробляю, я збагачую <..>» $[5,156]$.

Мистецькі принципи, про які йдеться, не були притаманні Д. Лідеру в співпраці 3 режисерами В. Люце у Челябінському театрі ім. С. Цвіллінга та М. Акімовим у Ленінградському театрі комедіï. $€$ всі підстави вважати, що вони сформувалися у Київський період й були зумовлені не лише творчою особистістю Д. Лідера, а й обставинами, у яких розгортався його мистецький пошук, та загальною тенденцією розвитку сценографії 196070-х років.

Оптика художнього бачення Д. Лідера неодмінно збільшуватиме масштаб узагальнення проблем i конфліктів постановок. Його просторові концепції віддзеркалюватимуть актуальні проблеми сучасності й водночас вестимуть розмову 3 глядачем про глобальні категорії буття. Творчий метод Д. Лідера, позначений ним формулою «проблема, конфлікт, незавершеність - багатозначність», надавав могутньої енергії саморозвиткові зорового образу, його часткової самореалізації поза режисерською партитурою вистави. Водночас, відштовхуючись від драматичного конфлікту, життєвих реалій, що спричинили розвиток головних подій і обумовили проблематику п'єси, сценограф засобами «пластичної режисури» створював просторові системи, які за рівнем художнього узагальнення виходили за межі драматургії.

Ці характеристики творчої діяльності Лідера притаманні майстрам дієвої сценографії «великого стилю», котрі прагнули «засобами свого мистецтва розкривати глобальні проблеми людського буття, створювати узагальнено-метафоричне середовище, вводити активно діючі образи, що були матеріалізованим і зримим утіленням сил або обставин, які протистояли героям спектаклів і виражали суть драматичного конфлікту» $[6,154]$.

Здавалося б, важко побачити хоч що-небудь спільне між драматургією «Такого довгого, довгого літа» М. Зарудного (Київський театр ім. І. Франка, 1974) й «Казками старого Арбату» О. Арбузова, як неможливо провести хоч якісь паралелі між режисурою С. Сміяна та А. Ефроса, котрий здійснив постановку п'єси О. Арбузова у Московському театрі на Малій Бронній (художник Д. Боровський, 1970). Проте, абстрагуючись від сюжетів, проблематики та ін. особливостей цих постановок, Г. Коваленко акцентує увагу на схожості підходу до вибудовування взаємодії героя i середовища. «Втім, подібні стосунки взаємодією в буквальному сенсі не назвеш. Контакти актора 
і сценографії опосередковані. У “Довгому, довгому літі” “вільний простір” варіюється — образні трансформації елементів пластики то розширюють його, то звужують. У “Казках" - він незмінний, оскільки середовище статичне, а елемент не володіє можливістю трансформації. Однак сам елемент середовища, його будівельна одиниця й у Д. Лідера й у Д. Боровського вибрані з одних і тих самих міркувань, "розраховані” за однаковими критеріями. Дерев'яний колодязь і навіс арбатського ганочка - за всієї їхньої достовірності та життєвої точності, за всієї підкресленої натуральності й справжності - не стільки предмети матеріального світу, скільки матеріалізація свідомості героїв, їхніх думок, що дивним чином втілилися у предметі. Це знак стосунків внутрішнього світу героїв і реальності...» $[7,155]$.

Можливість матеріалізувати думки, душевні боріння героїв вистави через побудову ії предметно-речового світу, образне моделювання в структурі внутрішнього світу драми, — відображають не лише тенденції розвитку сценографічного мислення, а й найважливіші аспекти нового характеру синтезу виражальних засобів театру. В цьому контексті слід розглядати й вихід художника за межі драматургії, і той вільний простір, що виник між сценографією та режисурою.

Досліджуючи «нову образність» у сценічному мистецтві 1960-1970-х років, театральний критик О.Ракітіна робить висновок про те, що нереалізовані режисерами потенції пластичного вирішення вистав «не пропадають зовсім, без сліду: їхня мовчазна присутність збагачує спектакль відтінками, обертонами, позбавляє його жорсткої та абсолютної детермінованості. Неповнота збігів - це свобода подиху спектаклю: для режисеpa, для художника, врешті, для глядача» $[8,78]$.

Однак «неповнота збігів» режисерських та сценографічних структур додавала «вільного подиху» виставі за умови рівності творчих потенціалів іï співавторів, мислення в системі єдиних естетичних координат - коли режисер, відчуваючи запропоновану образну природу сценічного простору, робив ії єдино можливою саме для цієї постановки. Поза цим процесом простір ніби замикався в собі, позбавляючи сценічну дію потрібних образних ресурсів.

На жаль, творчі потенціали й мистецькі критерії учасників театрального синтезу збігалися далеко не завжди. У1970-ті роки театральне життя України дедалі виразніше пульсувало напругою, найгостріші творчі суперечності виникали між інтегрованими до європейського театрального кон- тексту пошуками художників і схильною до стагнації режисерською практикою більшості театрів України.

Д. Лідер створював просторові концепції світу, не обтяжені веригами соціально-політичних кліше драматургічних творів. Саме тому побудована за принципами дієвої сценографії зорова партитура не вписувалася в режисерську концепцію постановок. Часто вона лише заважала вибудовувати накреслену деміургом театру логіку розвитку сценічної дії.

Скажімо, у виставі «Здрастуй, Прип'ять!» О. Левади (Київський театр ім. І. Франка, режисер С. Сміян, 1974) для Д. Лідера було принципово важливо, що між квітучими кронами яблунь $і$ металевим риштуванням, яке височіло по всьому радіусу сцени, між красою незайманої природи та сліпучими вогнями електрозварок велетенського будівництва - повсякчас відчувалося конфліктне протистояння. У пластиці існувало два образотворчих шари: «Полярних. Здавалося б, несумісних. Ворожих одне одному. Але для мене смисл був не в кожному з них окремо. Головне, що ці пласти наявні одночасно. Між ними - діалог, напружений, болісний, жагучий. Між ними конфлікт, боротьба, нез'ясована суперечність. Це було важливим насамперед. Образ - котрий виникає 3 того, що на сцені повнокровне і явне життя кожного образотворчого шару. Образ - що «спалахує» у зіткненнях цих пластів, що народжується і живе в моменти крайньої напруги кожного пласту, коли їхня взаємодія максимальна, загрожує вибухом. <..>

Металеве риштування та квітучі яблуні існують одночасно; точніше, обидва ці образи - частина одного образу, котрий ніби коливається між двома своїми граничними іпостасями. I не тільки коливається, а живе - тому що в основі своїй виражає споконвічні протиріччя: природа і творіння людських рук, поезія і розрахунок...» [2, 194-195]. Однак у виставі не реалізованим залишилося головне - «конфлікт, боротьба, нерозв'язні суперечності». На сцені розташувалися й квітучі яблуні, й металеве риштування, але це було «мирне» співіснування, а не протистояння двох проявів життя.

Навіть уже отримавши сценічне втілення, за умови певної адаптації до постановочного рівня того чи того творчого колективу, зорові образи й надалі втрачали свою багатовимірність у процесі експлуатації вистави. Картиною «вселенського погрому» завершує творчий портрет Д. Лідера театральна художниця Т. Сельвінська: «Чудово виконане київськими майстрами стоїть оформлення 
на знаменитій сцені найстарішого театру, але мертвим багатством:

софіти "Ярослава Мудрого" соромливо прикриті м'ятими падужками, нема вже й руки-фрески, не рухаються риштування, і не ходять ними люди, не зіштовхуються одночасно дві епохи;

скриня-чарівниця грає ординарну роль стандартного павільйону. Не ловлять стулки перехожих, сховані переходи, численні лазівки, нема фантасмагорії, вигадки, карнавалу;

немає і потрійного театру в “Людині з Ламанчі”, немає філософії, ішомовності, ідеї.

$€$ непередбачена несумісність декорації та дії.

$\epsilon$ хвороба нашого часу - рідкісними $\epsilon$ режисери, ще більш рідкісними театри, що вміють не лише використовувати, застосовувати, експлуатувати запропоноване художником дієве оформлення, а й уже задумувати його таким - одним із головних дійових осіб спектаклю» $[9,65]$.

У роки нереалізованих театром творчих ідей Д. Лідера його роботи отримували визнання на міжнародному форумі Празьких квадрієнале, численних всесоюзних виставках художників театру і широко висвітлювалися у театральній критиці та мистецтвознавчих дослідженнях. В останніх зазвичай образний потенціал сценографії Д. Лідера розглядався без урахування іiі сценічного втілення. Так, у передмові до книги «Художник театру Данило Лідер» Г. Коваленко пише: «... аналізуючи творчість митця, ми будемо говорити насамперед про театр художника, яким цей театр постає в його замислах, в його ескізах і макетах, звертаючись до здійсненого спектаклю в тих випадках, коли ідеї сценографа знаходили у цьому спектаклі продовження» $[7,7]$.

У період стрімкого виокремлення сценографiї у самостійний вид мистецтва і накопичення негативного досвіду співпраці з режисерами самозбереження мистецької особистості художника формувало певні методологічні засади створення просторово-пластичних партитур, що не передбачали узгодження з режисерською інтерпретацією п'єс. Суттєву роль у цьому процесі відіграє остаточне виокремлення тих світоглядних засад, тих категорій аналізу драматургічного матеріалу, котрі обумовлювали цілісну концепцію сценічного прочитання твору.

У 1990 році, аналізуючи макети і ескізи, створені в різні періоди творчої діяльності, Д. Лідер акцентує увагу на «конструктивному коді», що виражає концепцію його ставлення до образу: «В моєму ескізі («Маскарад» М. Лермонтова, 1947. - В. Ф.) є одна риса, котра була натяком на те, до чого я прийду через багато-багато років. Тут, у центрі цієї структури, намальована природна анфілада кімнат, але у театральній реальності вона була немовби нескінченна. Вона виходила у служби театру, до меблевого цеху, пронизувала якісь ще майстерні й виходила у двір. Там уже, звісно, не було нічого видно, проте сходилося все до однієї перспективної точки. Ось цей-бо маршрут ніби руйнує природний, реальний вигляд декорації - безкінечний маршрут у небуття. Він, на мою думку, дав цікаву заявку як на ті часи.

Власне, що ж таке цей маршрут? Його можна назвати великою сферою змісту, "крупняк", як я його називаю. А те, що я зробив у “Маскараді”, немов побутове підтвердження цього маршруту. Це дуже важливо запам'ятати, бо на цій концепції будуватимуться майже усі мої спектаклі у майбутньому» [10].

Цей «маршрут», зазначає Д. Лідер, «пройде крізь життєву лінію й приведе до "Короля Ліра" (Малий театр, Москва, режисер Л. Хейфець, 1979 - В.Ф.). На ескізі видно ритми, вони візуально приводять нас до точки сходу й від точки сходу - ритмічно - до великого, навіть безкінечного ряду. Весь цей код можна пояснити дуже просто. Цей код, що схематично представляє нам зміст світу через поняття безкінечності у малому й безкінечності у великому. I якщо коротко схарактеризувати, що ж $є$ світом малим і світом категорії більшого, то категорія великого - це загальний об' єктивний рух розвитку суспільства, природи та світу, а мала категорія - це побут, родина, це суперечності між, у цьому разі, Ліром та його дочками, з людьми, які оточують його. Тут сюжет $\epsilon$ мірою малого.

Варто звернути увагу на одну річ у цьому ескізі: коли виганяли Ліра з його палацу разом із блазнем, останній висмикнув з усієї структури королівства Ліра іï малу частину, котра могла б слугувати людині у вигнанні нагадуванням про його колишню могутність. От стоїть уже збожеволілий Лip, увесь засмиканий, обшарпаний $<\ldots>$ стоїть 3 вінком на голові, десь сплів собі у степу чи йому сплели. Він повсякчас спілкується з малою структурою. I він іiі препарує, намагається іноді розняти на шматочки. Нормальна людина ніколи таким «науковим аналізом» займатися, звісно, не буде, але безтямний - буде. I я вхопився за можливість прокреслити свою головну філософську лінію - про те, що інтерес людини має спрямовуватися саме на малий світ. I не лише у мистецтві, i не лише для Ліра, а для будь-якої людини, для будь-якого державного чи недержавного діяча. 
Саме у цих малих категоріях закладено чимало з того, що ми пропускаємо, і хапаємося ми за ці речі, коли малий світ уже виростає і нас обходить. I ми запізнюємося, і так виникають цілі категорії трагедій у господарстві, управлінні, промисловості й будь-де» [10].

У період роботи з режисером І. Молостовою над виставою «Вишневий сад» А. Чехова на малюнках і ескізах Д. Лідера не було «кодового визначення». Художник побачив це вже пізніше, коли готував роботи на виставку. «Ці два рисунки опинилися у майстерні випадково поряд. I я раптом зрозумів, що “Вишневий сад” — це “Король Лір", тільки навпаки. Тобто такий же маршрут, але якщо у "Королі Лірі" - згори вниз, у малий світ, то у "Вишневому саду" - знизу вгору, до точки сходу. I я почав виконувати виставочні варіанти для порівняння, здавалося б, двох зовсім несхожих драматургічних матеріалів.

Вочевидь сама сутність руху до образу, драматургія, вивела мене знову до категорій малого і великого світів. Інтуїтивно йдучи до смислу цієї п'єси, мені чомусь захотілося вийти на довгий маршрут. Він потім отримав назву “історичний маршрут”, маршрут у глибину часу» [10].

У виставі «Вишневий сад» (Київський театр ім. Лесі Українки, режисер I. Молостова, 1980?) сліпучо-білі, напівпрозорі, неначе мереживні від сонячного мерехтіння стіни родинного будинку Гаєвих видавалися кипінням квітучих вишневих гілок, що хвилюються на вітрі. Їхня «жива», «дихаюча» біла плоть вривалася до анфілади кімнат, що довгим маршем розчинялися у глибині сцени. Крізь біле мереживо «вишневого саду» проглядав інтер'єр усіх трьох кімнат будинку: ампір початку XIX століття, зал у стилі еклектики середини XIX століття і найближче до глядачів - кімната у стилі модерн початку $\mathrm{XX}$ століття. Три шари побуту встановлювали зв'язок часів, збирали в єдине ціле картину життя поколінь, розсували межі часу до такого стану, коли за Зінгерманом «...минуле і майбутнє вторгається на сцену як самостійно діючі сили, безпосередньо впливаючи на драматичних персонажів» $[11,40]$, відтак — «...сьогодення втрачало у Чехова свою обгрунтованість і непорушність, у певному сенсі виявляючись лише моментом переходу від минулого до майбутнього» $[11,40]$.

«Що найцікавіше - у цьому великому маршруті наявні подробиці, сотні подробиць. Вони ніби беруть участь у цій філософії. Саме побутом вибудувано цей маршрут. Саме 3 побутових подробиць вирощено історичний “крупняк”. Таке відчуття, що я там був, жив, знаю всі закутки. Тобто я не візуально ставлюся до змісту, я перебуваю в ньому.

Моя присутність і вторгнення у кожну людину, в іiі характер приводить мне до дуже стислої думки, що вишневий сад розквітнув напередодні своєї загибелі, так, ніби лучина або свічка, догораючи, в останню мить спалахують полум'ям. Це можна перевірити: запаліть сірник і тримайте його до останнього згорання - i ви обов'язково отримаєте у фіналі спалах.

А загибель саду - це послідовне згасання феєрії світла, через усі шари контрових променів, звідси й білі, пронизані світлом кольори. I коли сад має бути вирубано, чути звук сокири - i ми у всій цій структурі отримуємо просторові діри. Тому що світло прибране і з'являється темрява, а темрява розглядається як просторова діра. I на всі удари сокири згасало світло і виникало ще більше дір. I на останньому ударі зникали останні клоччя світла. І коли зникало все світло, ми у темряві від маленького бічного голубуватого світла бачили весь навал культури - меблі, картини, шафочки, столики, крісла тощо. Все це ніби якесь звалище, хаос, звідки вийнято життя» [10].

Наведені фрагменти розповіді Д. Лідера про матеріалізовані в ескізах образи-задуми постановок «Король Лір» і «Вишневий сад» виходять далеко за межі створення зорового образу вистав. По суті, художник пропонує цілісний погляд на сценічне прочитання драматургії.

Безперечно, Д. Лідер чудово усвідомлював ідею колективної роботи над виставою, що засвідчує практика численної когорти його учнів. Сталі режисерсько-сценографічні тандеми 1980-1990-х років відіграють суттєву роль в оновлені українського театру.

Плідною співпрацею з режисурою позначене й останнє десятиліття творчої діяльності Лідера. У 1980 році він прийняв пропозицію С. Данченка повернутися на посаду головного художника Київського театру ім. І. Франка. Безперечно, С. Данченко чудово був обізнаний не лише з мистецьким доробком художника, а й з принципами, якими він керується у своїй роботі. Проте це не стало на заваді втіленню режисерських концепиій постановок «Дядя Ваня» А. Чехова (1980), «Візит старої дами» Ф. Дюрренматта (1983), «Тев'є-Тевель» за Шолом-Алейхемом (п'єса Г. Горіна; 1989).

$\mathrm{y}$ цих спектаклях, що стали етапними для розвитку української театральної культури, образні системи Данченка-Лідера (попри принципово різні методи їхньої творчої діяльності) створювали сценічні всесвіти, які охоплювали різні сфери 
та рівні життя, де загальнолюдське було органічно пов'язане 3 таємницями людської психіки i багатоголоссям повсякденності. У налагоджені співавторства режисера і сценографа не останню роль відіграла притаманна С. Данченкові оптика художнього світобачення, котра посилювала інтелектуальний зміст його найкращих вистав, фокусуючи увагу насамперед на сенсах життя - не на прикметах. Категорії, що ними оперував режисер, моделюючи картину світу, чи не найближче збігалися із прагненням сценографів «великого стилю» розкривати засобами свого мистецтва глобальні проблеми людського буття.

Однак, підбиваючи підсумки творчих пошуків, Д. Лідер із сумом констатував: «Увесь цей період, коли ти сам думаєш та викладаєш своє розуміння, коли ти сам по собі - звичайно, розраховуючи на певний колективний процес, — цей період займає дуже багато часу й приносить дуже мало радощів. Виникає бажання все привести у завершений вигляд. Не хотілося б далі це все віддавати у чужі руки - у процес, де все розбирається на частини. Така вже доля театрального художника. Коли віддається один компонент до одного цеху, інший - до іншого, потім усе це потрапляє у розпорядження режисера, помічника режисера. Робітники сцени, встановлюючи, починають по-своєму трактувати. I ось тут уже починаються прикрощі, адже якби цей процес можна було б поєднати в одній особі, - що, звісно, неможливо, - то, як на мене, цей процес був би ідеальним для театрального художника. Я шкодую, що я — не режисер» [10].

\section{Джерела та література}

1. Стенограма виступу Д. Лідера на конференції театральних художників «Традиції і новаторство в мистецтві». 26 вересня 1966. - К. : Українське театральне товариство.
2. Лидер Д. Размышления художника // Советские художники театра и кино' 79. - М. : Советский художник, 1981.

3. Лідер Д. Образ вистави // Український театр. - 1972. № 4.

4. Березкин В. Даниил Лидер. // Советские художники театра и кино' 75. - М. : Советский художник, 1977.

5. Клековкін О. Данило Лідер: Людина та іiї простір // Кле-

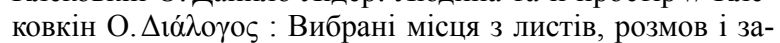
писників / Олександр Клековкін. - Ін-т проблем сучас. мистецтва НАМ України. - К. : Арт Економі, 2016.

6. Березкин В. Сценография второй половины 70-х годов. Вопросы театра. Всероссийское театральное общество / В. Березкин. - М. : 1981.

7. Коваленко Г. Художник театра Даниил Лидер / Г. Коваленко. - М. : Искусство, 1980.

8. Ракитина Е.Эти независимые художники // Театр. 1974. - № 4.

9. Сельвинская Т. Даниил Лидер // Театр. - 1974. — № 7.

10. Документальний фільм «Данило Лідер», Центр творчих ініціатив, 1991.

11. Зингерман Б. Театр Чехова и его мировое значение / Б. Зингерман. - М. : РИК Русанова, 2001.

\section{References}

1. Stenohrama vystupu D. Lidera na konferentsii teatralnykh khudozhnykiv «Tradytsii i novatorstvo v mystetstvi». - 26 veresnia 1966. - K. : Ukrainske teatralne tovarystvo.

2. Lider D. Razmyishleniya hudozhnika // Sovetskie hudozhniki teatra i kino' 79. - M. : Sovetskiy hudozhnik, 1981.

3. Lider, D. Obraz vystavy // Ukrainskyi teatr. - 1972. — № 4.

4. Berezkin, V.Daniil Lider. // Sovetskie hudozhniki teatra i kino' 75. - M. : Sovetskiy hudozhnik, 1977.

5. Klekovkin, O. Danylo Lider: Liudyna ta yii prostir //

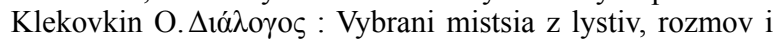
zapysnykiv / Oleksandr Klekovkin. - In-t problem suchas. mystetstva NAM Ukrainy. — K. : Art Ekonomi, 2016.

6. Berezkin, V. Stsenografiya vtoroy polovinyi 70 -h godov. Voprosyi teatra. Vserossiyskoe teatralnoe obschestvo / V. Berezkin. - M. : 1981.

7. Kovalenko, G. Hudozhnik teatra Daniil Lider / G. Kovalenko. - M. : Iskusstvo, 1980.

8. Rakitina, E. Eti nezavisimyie hudozhniki // Teatr. — 1974. — \# 4.

9. Selvinskaya, T. Daniil Lider // Teatr. - 1974. — \# 7.

10. Dokumentalnyi film «Danylo Lider», Tsentr tvorchykh initsiatyv, 1991.

11. Zingerman, B. Teatr Chehova i ego mirovoe znachenie / B. Zingerman. - M. : RIK Rusanova, 2001. 